\title{
SOCIAL BELIEFS FOR THE REALIZATION OF THE SPEECH ACTS OF APOLOGY AND COMPLAINT AS DEFINED IN CILUBA, FRENCH, AND ENGLISH ${ }^{1}$
}

\author{
Kashama Mulamba
}

\begin{abstract}
Most cross-linguistic studies of speech acts have dealt mainly with two languages, a native language and a second or foreign language (Carrell and Konneker 1981; Castello 1981; Blum-Kulka 1982; Daikuhura 1986; Eisenstein1986; Wieland 1989; Chen Rong 1993, 2001; Sifianou 2001; Lee 2004, 2005). Neither have they dealt with an African language as the first language. The present study investigates a multilingual situation where the native speakers of Ciluba, French, and English are compared to the trilingual speakers of the three languages in terms of the realization of the speech acts of apologizing and complaining. It considers the social beliefs of the subjects of the four language groups for the realization of the two speech acts. The study is part of a larger study that was designed to discover the norms of the three languages under investigation and to see how people speaking a second and a foreign language, with different levels of fluency in each, can participate in the activity of the speech communities of the two languages without violating their socio-cultural norms, and what impact, if any, their knowledge of these languages has on each of the languages they speak. ${ }^{2}$ Data for the larger study was collected by means of a written questionnaire, role plays, and direct observation.

The data and results presented and discussed in this paper come from the written questionnaire administered to the monolingual English and French speakers and trilingual speakers native in Ciluba; and from the same version of the questionnaire administered orally to the monolingual Ciluba speakers. ${ }^{3}$ It was found that for the realization of the speech acts of apologizing and complaining, Luba sociocultural beliefs were different from those of English and French, which are similar. In contrast to French and English, in Ciluba social distance and relative power between the participants play an important role in deciding whether the speech acts can be performed or not. The results also revealed that, despite the difference which exists between Ciluba and the other two languages, i.e., French and English, some subjects from the group of Ciluba monolingual subjects showed some similarities with the groups of French and English monolingual subjects in their responses to some items in the questionnaire. This deviation of some of the native speakers of Ciluba from their social beliefs was hypothesized to be a result of their contact with an urban environment and its mixed culture.
\end{abstract}

Keywords: Trilingual speakers; Pragmatic study; Metapragmatics; Socio-cultural norms; Apology; Complaint.

${ }^{1}$ The completion of this study was made possible by a grant from the Fulbright Organization and the Office of Research at Ball State University, Muncie, Indiana (USA). I remain indebted to these two institutions.

${ }^{2}$ The results presented here are taken from a larger study titled "Apologizing and Complaining in Ciluba, French, and English: Speech Act Performance by Trilingual Speakers in Zaire.”

${ }^{3}$ Since the monolingual speakers of Ciluba have little or no education, they were administered the questionnaire orally. 


\section{Introduction}

In a multilingual society such as the Democratic Republic of the Congo, different languages may serve different functions, such as wider communication, i.e., national and international communication; education at different levels, and religion. The three languages under investigation, Ciluba, French, and English, are used in different ways in the Democratic Republic of the Congo.

Ciluba, which is the language of the investigation, is one of the four vernacular languages, including Lingala, Swahili, and Kikongo, used in the media and in elementary education along with French. It consists of the two varieties spoken in the two Kasai Provinces, the Eastern and the Western Kasai Provinces. A variety of Ciluba is also spoken in the Katanga Province. French is a "second" language in the Congo. It is the language of government administration and thus is considered the "official" language. French is also the language of education, being introduced gradually from elementary education through higher education. In addition, a large sector of society uses French as the principal language of communication inside and outside their home. In contrast to French, English is taught in the Democratic Republic of the Congo as a "foreign" language. Outside the classroom, it is used mainly by a minority of teachers of English and students majoring in English at colleges and universities, and by individuals learning English at the American and British Language Centers.

\section{Population}

The description of the four groups of informants presented here is based on information gathered from items 1-8 in the questionnaire ${ }^{4}$ (see Appendix). The population consisted of four major language groups of subjects, composed of the monolingual speakers of Ciluba, the monolingual speakers of French, the monolingual speakers of English, and the trilingual speakers of Ciluba, French, and English. Each group consisted of female and male informants. The subjects volunteered for the study. All the subjects were contacted through personal contacts and acquaintances.

\subsection{Ciluba monolingual group}

The Ciluba monolingual group of informants consisted of Congolese who were members of a local Luba church where the whole worship was conducted in Ciluba. They used Ciluba as their language of communication at home and barely spoke Lingala, the main vernacular language spoken in Kinshasa. The selection of these subjects was done by means of announcement in the church. The group consisted of 50 subjects, 25 female and 25 male subjects, who volunteered to respond to the oral version of the questionnaire. With respect to their education, 14 of the 25 male subjects had completed six years of elementary education. Six of them dropped out of high school after two years. Five had completed six years of high school but failed the government exam and did not receive a high school diploma. Eight of the 25 female subjects had completed elementary education. Three had reached the 5th grade of high school. Nine

\footnotetext{
${ }^{4}$ Only the English version of the questionnaire is included in this paper.
} 
of the remainder had completed five years of elementary education and five had reached only the $4^{\text {th }}$ grade of elementary education. The ages of the group ranged between 21 and 25.

\subsection{French monolingual group}

Not being able to travel either to France or to Belgium due to financial difficulties, I selected the French monolingual subjects in Kinshasa. They consisted primarily of those subjects whose parents were French or Belgian nationals who worked at the embassies, French and Belgian schools, Congolese high schools, colleges and universities, and at French and Belgian private companies in Kinshasa. Their native language was French (including Belgian French). Among them were also a few Congolese subjects born and raised either in Belgium or in France, and whose language of communication at home was French. The subjects were high school seniors at the time of this investigation. The selection for this group was done through friends who were teaching in those schools. Seventy written questionnaires were distributed to this group. Sixty three questionnaires were returned. There were 33 female respondents and 30 male respondents. The ages ranged between 15 and 20.

\subsection{English monolingual group}

When I came back to the U.S., I selected the monolingual speakers of English. All English monolingual subjects were Americans in their freshman year at Ball State University in Muncie, Indiana. Their selection was made possible thanks to friends who were teaching freshman composition in the Department of English. As I did for the selection of French monolingual speakers, I personally talked to their classes and explained the object of the study. Fifty subjects were administered the written questionnaire, but only 36 subjects returned it, of whom 23 respondents were female and 13 male. Their ages ranged between 15 and 20.

\subsection{Congolese trilingual group}

The majority of the Congolese trilingual informants were freshman and sophomore college students. All the female informants were students in the Department of English at Institut Superieur Pedagogique de la Gombe, a women's Teachers College, located in Kinshasa, the capital city of the Democratic Republic of the Congo, where I taught English before I came to the United States. As future teachers of English at high schools, the subjects were required to use English in their daily encounters with their teachers and classmates. They all belonged to an English Club, whose objectives were to promote the use of the English language among its members and to try to learn about English native speakers' culture. All the male subjects were from Congolese colleges and universities in the capital city. They belonged to a club named The Great Guys whose objectives were similar to those of the English Club. I spent seven months in the Congo attending and participating in all their meetings, which took place once a week on Sundays. Seventy questionnaires were distributed to the subjects and all 70 were 
returned, among which there were 35 female respondents and 35 male respondents. All the informants in this group were Congolese. They were fluent both in Ciluba and French. Apart from English, which was of common use among the subjects, the use of either Ciluba or French at home or outside the home depended on the situations in which the subjects found themselves; and also on the individuals with whom they interacted. The subjects had a good mastery of English, too. Their ages ranged from 21 to 25 .

\section{Methodology and design}

As I mentioned above, I spent seven months in the Congo investigating the sociocultural norms for the realization of the speech acts and their performance by Ciluba and French monolingual speakers and by trilingual speakers. ${ }^{5}$ The collection of the data for the socio-cultural norms of English and the performance of the two speech acts by monolingual speakers of English took place in the United States after I returned from the Congo. The focus of the present paper is on the social beliefs of the three language groups for the realization of the two speech acts. In other words, the paper presents the sociolinguistic baselines for the realization of each of the speech acts as defined by the socio-cultural contexts of each language.

The methodology for the study was developed on the basis of two small pilot studies. The first study entitled "Sociolinguistic clash: An experience of a foreign language learner of English," consisted of a survey of some of the social contexts in which speech acts such as apologizing and expressing gratitude are performed in American and various African and Asian cultures and how breaching the different norms can lead to sociolinguistic clashes among the participants in a conversation. The data for this study were collected by means of interviews and natural observation of the interactions by the subjects. The second study, "Complaint and persuasion: Speech act performance by native and second language speakers of French and English,” consisted in comparing the performance of the speech acts of complaint and persuasion in English, French, and several African languages by speakers of these languages. The data were collected by means of interviews and role plays by the subjects. The role plays were videotaped.

The overall methodology for the collection of the data consisted of the following steps:

Step I: I first administered a written questionnaire to the French, English, and trilingual speakers; and an oral version of the same questionnaire to the Ciluba monolingual speakers. The questionnaire consisted of two main parts. In the first part, I gathered general information about the informants; in the second part, I asked questions to elicit the social beliefs of the language groups for the realization of the speech acts of apologizing and complaining, i.e., to see as Fishman (1965) advises, who says what to whom, when and how. For instance, I examined when and how a speaker of each language believes that it is appropriate to apologize and complain. The responses of the monolingual speakers of Ciluba were recorded. The written and the oral versions of the questionnaire elicited the following information: The sex of the informant, age, educational background, native language, other languages spoken, languages frequently

\footnotetext{
${ }^{5}$ The results of the production of the two speech acts are not discussed in this paper.
} 
used at home or outside the home for communication, the contexts in which the informant would be likely to use the speech acts under investigation, and who she or he would or would not interact with when performing each speech act.

Step II: I then analyzed informants' responses to the questionnaire. The analysis consisted in finding out the percentages of the informants' responses to different items and in explaining the social beliefs defining the paradigms for the realization of the speech acts of apologizing and complaining. The significance of each response was attested by the use of the chi-square.

\section{Analysis of the responses}

Altogether, 190 written questionnaires were distributed and 169 returned. (For information about the number of questionnaires returned by each language group see 2.1-2.4 above). Items 1-8 on the questionnaire provide general background information about the population. Items 9A and 9B on the questionnaire asked the subjects to say whether they would or would not express an apology or a complaint to different categories of individuals mentioned.

\subsection{Results and discussion}

This section will focus on the responses provided by the language groups of both monolingual speakers of Ciluba and trilingual speakers of Ciluba, French, and English. For the sake of clarity, each item will be analyzed and discussed separately. The responses from the French and English monolingual speakers relevant to these three items are not discussed because all the subjects in these two language groups, i.e., 100 percent of the subjects in both groups, responded that they would apologize and complain to all the categories of individuals mentioned in the items. The analysis consists in determining whether the informants from the monolingual speakers of Ciluba and those from the trilingual group establish similar socio-cultural contexts for the realization of the two speech acts. In order to do so, I informally observed the speech community under investigation, and apart from my own intuitions as a native speaker of Ciluba, I also referred to literature on African systems of kinship and marriage which, in some way, are similar to those of the Luba tribe.

\subsubsection{Subjects' responses to item 9A}

In this item, the subjects were asked to say whether they would or would not apologize to the categories of individuals listed in the item (see Appendix). The responses of the monolingual speakers of Ciluba and those of the trilingual speakers to this item are presented in Tables 1 and 2 below. The data, as presented in Tables 1 and 2, do not match my expectations as a native speaker of Ciluba. In their responses, the subjects of both groups seem to indicate that they can apologize to all the categories of individuals suggested in the item. While this may be true for the monolingual speakers of French and English, it is not actually the case for those of Ciluba. As will be shown in the discussion that follows, the expression or the non-expression of the act of apology, in 
the Luba speech community, is determined by the relationship which exists among individuals. A boss, for instance, is not expected to apologize to a subordinate for an offense committed, neither is a friend for a trivial offense committed against another friend. In order to interpret these results, one has to relate to the setting and social structure which determine why, when and to whom an apology may be expressed. As Rubin (1983) suggests,

It is important to have an understanding of how a society approaches social interaction in order to send and interpret messages properly. Given this understanding, we can predict where communication can break down, when the goals of two individuals belonging to different value systems come into conflict. (Rubin 1983: 16)

Tables 1 and 2 indicate that 100 percent of the subjects in the Ciluba monolingual group and 100 percent of the subjects in the trilingual group responded that they would apologize to their boss. The data reveal also that 32 percent of the subject in the Ciluba monolingual group and 20 percent of the subjects in the trilingual group responded that they would apologize to a subordinate. The contrast which is shown by the difference of proportions between the respondents who said they would apologize to the boss (100\% in each language group) and those of the subjects who said they would apologize to the subordinate (32\% in the Ciluba monolingual group and $20 \%$ in the trilingual group), i.e., less than half of subjects in each language group, allows for the interpretation that Ciluba social beliefs allow for the apology to be expressed upwards rather than downwards. The few subjects who responded that they would apologize to the subordinate may have been influenced by the urban environment within which they live.

Table 1: Percentages of Ciluba monolingual subjects' responses to item 9A

\begin{tabular}{|l|l|l|l|l|}
\hline $\begin{array}{l}\text { Categories of } \\
\text { individuals }\end{array}$ & Responses & $\begin{array}{l}\text { Female } \\
\text { subjects } \\
\mathrm{n}=25\end{array}$ & $\begin{array}{l}\text { Male } \\
\text { subjects } \\
\mathrm{n}=25\end{array}$ & Total \\
\hline Boss & $\begin{array}{l}\text { Yes } \\
\text { No }\end{array}$ & $\begin{array}{l}25(100 \%) \\
0(0 \%)\end{array}$ & $\begin{array}{l}25(100 \%) \\
0(0 \%)\end{array}$ & $\begin{array}{l}50(100 \%) \\
0(0 \%)\end{array}$ \\
\hline Subordinate & Yes & $\begin{array}{l}6(24 \%) \\
19(76 \%)\end{array}$ & $\begin{array}{l}10(40 \%) \\
15(60 \%)\end{array}$ & $\begin{array}{l}16(32 \%) \\
34(68 \%)\end{array}$ \\
& No & $6(24 \%)$ & $4(16 \%)$ & $10(20 \%)$ \\
\hline Co-worker & Yes & $19(76 \%)$ & $21(84 \%)$ & $40(80 \%)$ \\
& No & $25(100 \%)$ & $20(80 \%)$ & $45(90 \%)$ \\
\hline Store clerk & Yes & $0(0 \%)$ & $5(20 \%)$ & $5(10 \%)$ \\
& No & $25(100 \%)$ & $25(100 \%)$ & $50(100 \%)$ \\
\hline Neighbor & Yes & $0(0 \%)$ & $0(0 \%)$ & $0(0 \%)$ \\
& No & $6(24 \%)$ & $9(36 \%)$ & $15(30 \%)$ \\
\hline Friend & Yes & $19(76 \%)$ & $16(64 \%)$ & $35(70 \%)$ \\
\hline Mother & Yes & $7(28 \%)$ & $10(40 \%)$ & $17(34 \%)$ \\
& No & $18(72 \%)$ & $15(60 \%)$ & $33(66 \%)$ \\
\hline Father & Yes & $7(28 \%)$ & $10(40 \%)$ & $17(34 \%)$ \\
& No & $18(72 \%)$ & $15(60 \%)$ & $33(66 \%)$ \\
\hline
\end{tabular}


Table 2: Percentages of trilingual subjects' responses to item 9A

\begin{tabular}{|c|c|c|c|c|}
\hline $\begin{array}{l}\text { Categories of } \\
\text { individuals }\end{array}$ & Responses & $\begin{array}{l}\text { Female } \\
\text { subjects } \\
\quad \mathrm{n}=35\end{array}$ & $\begin{array}{l}\text { Male } \\
\text { subjects } \\
\qquad \mathrm{n}=35\end{array}$ & $\begin{array}{l}\text { Total } \\
\mathrm{n}=70\end{array}$ \\
\hline Boss & $\begin{array}{l}\text { Yes } \\
\text { No }\end{array}$ & $\begin{array}{l}35(100 \%) \\
0(0 \%)\end{array}$ & $\begin{array}{l}35(100 \%) \\
0 \quad(0 \%)\end{array}$ & $\begin{array}{l}70(100 \%) \\
0(0 \%)\end{array}$ \\
\hline Subordinate & $\begin{array}{l}\text { Yes } \\
\text { No }\end{array}$ & $\begin{array}{l}6(17 \%) \\
29(83 \%)\end{array}$ & $\begin{array}{lr}8 & (23 \%) \\
27 & (77 \%)\end{array}$ & $\begin{array}{l}14(20 \%) \\
56(80 \%)\end{array}$ \\
\hline $\begin{array}{c}\text { Co- } \\
\text { worker }\end{array}$ & $\begin{array}{l}\text { Yes } \\
\text { No }\end{array}$ & $\begin{array}{l}35(100 \%) \\
0 \quad(0 \%)\end{array}$ & $\begin{array}{l}35(100 \%) \\
0 \quad(0 \%)\end{array}$ & $\begin{array}{l}70(100 \%) \\
0 \quad(0 \%)\end{array}$ \\
\hline Store clerk & $\begin{array}{l}\text { Yes } \\
\text { No }\end{array}$ & $\begin{array}{l}35(100 \%) \\
0 \quad(0 \%)\end{array}$ & $\begin{array}{l}35(100 \%) \\
0 \quad(0 \%)\end{array}$ & $\begin{array}{l}70(100 \%) \\
0 \quad(0 \%)\end{array}$ \\
\hline Neighbor & $\begin{array}{l}\text { Yes } \\
\text { No }\end{array}$ & $\begin{array}{l}35(100 \%) \\
0 \quad(0 \%)\end{array}$ & $\begin{array}{l}35(100 \%) \\
0 \quad(0 \%)\end{array}$ & $\begin{array}{l}70(100 \%) \\
0 \quad(0 \%)\end{array}$ \\
\hline Friend & $\begin{array}{l}\text { Yes } \\
\text { No }\end{array}$ & $\begin{array}{l}35(100 \%) \\
0(0 \%)\end{array}$ & $\begin{array}{l}35(100 \%) \\
0 \quad(0 \%)\end{array}$ & $\begin{array}{l}70(100 \%) \\
0(0 \%)\end{array}$ \\
\hline Mother & $\begin{array}{l}\text { Yes } \\
\text { No }\end{array}$ & $\begin{array}{l}35(100 \%) \\
0 \quad(0 \%)\end{array}$ & $\begin{array}{l}35(100 \%) \\
0 \quad(0 \%)\end{array}$ & $\begin{array}{l}70(100 \%) \\
0(0 \%)\end{array}$ \\
\hline Father & $\begin{array}{l}\text { Yes } \\
\text { No }\end{array}$ & $\begin{array}{l}35(100 \%) \\
0(0 \%)\end{array}$ & $\begin{array}{l}35(100 \%) \\
0 \quad(0 \%)\end{array}$ & $\begin{array}{l}70(100 \%) \\
0 \quad(0 \%)\end{array}$ \\
\hline
\end{tabular}

In order to see how significant the results are and in order to confirm my interpretation of the results, a chi-square test ${ }^{6}$ comparing the responses of the two language groups was performed. The result shows that the difference in the proportions of these two language groups with respect to expressing an apology to a subordinate is not significant (chi-square of 2.240, $\mathrm{p}=0.134>0.001$, $\mathrm{df}=1$ ). In other words, the two groups of subjects present a similar social belief, i.e., a number of subjects (less than half) in each group can be said to deviate from the social beliefs of the Luba society which accept that the subordinate apologize to the boss, but not the opposite.

It is culturally shared knowledge among African people, in general, and among the Baluba, ${ }^{7}$ in particular, that the behavior of an individual towards another, in the same social community, is determined by the social rank. This rank is determined by many factors including seniority, age group, and sex of the participants. A lack of consideration for social rank in interaction among the members of the speech community is considered to be a deviation from the social beliefs.

A social belief which shows how the behavior of an individual is determined by the social rank in the Luba tribe is, for instance, that an individual of a lower social rank, e.g., a villager, a subordinate, or a person belonging to a younger age group, such as a younger brother or sister, is expected to apologize to a person of a higher social rank, such as a chief, a boss, or an individual belonging to an older age group, that is an older brother or sister, but not the opposite.

${ }^{6}$ In order to control the overall probability of making a Type I error, i.e., rejecting a true hypothesis, the significance level for each of the chi-square tests in the present study is set to the 0.001 level.

${ }^{7}$ Speakers of Ciluba. Muluba is the singular of Baluba. 
An illustration of how some African societies view the distance which may exist between an individual of higher social rank such as a chief or any member of his family, and another of a lower social rank, i.e., a villager, is provided in Kuper's (1975) account of the "Kinship among the Swazi," where he describes the Swazi king's reaction to a family council's decision. Kuper (1975) notes,

When the polygynist Kambi Maseko died, his wives included a daughter of the king Mswati (by the levirate) and one with the clan name of the paternal grandmother. The family council appointed the latter as main wife, and announced their choice to the ruling king. When he found out that a royal princess had been overlooked, he told the council to reconsider their decision, for it is not law that the king should eat on the ground while the dog eats from the plate. (Kuper 1975: 110)

The metaphor used by the king to refer to a person of a low social rank speaks for itself. Interestingly enough, the relationship, as illustrated here, between the Swazi people and their king is similar to that between the Luba people and their chiefs. As Kuper (1975) reports, princes and chiefs exact more respect and obedience than commoners. They are, therefore, the ones who should be apologized to and not the opposite. As Brown and Levinson's $(1978,1987)$ model suggests, one can predict that people would apologize more to higher status and powerful individuals than to lower status and less powerful ones. Brown and Levinson argue that the greater the social distance, the heavier the weighting of the Face Threatening Act (FTA).

From the responses provided by the majority of the subjects in both groups, it can be concluded that when the relationship between the participants is that of unequal status, i.e., an individual of a higher social rank interacting with an individual of a lower social rank, e.g., boss to subordinate, chief to villager, old person to young person, the Luba social beliefs require, in order to show respect and submission, that the offender of the lower social rank, i.e., the subordinate, the villager, the younger brother or sister express an apology to the offended individual of the higher social rank, i.e., the boss, the chief, or the older person. The opposite, which is not permitted, would be a mitigation of power.

Both the expression of apology by the offender of the lower social rank and the non-expression of apology by the offender of the higher social rank account for the maintenance of distance between the individuals of unequal status. These results mirror Holmes's (1989) findings on sex differences and apologies in New Zealand, where most apologies occur between equals, and both sexes direct more apologies upwards than downwards.

Among the Baluba, the chief is to be considered a very high-ranking and powerful individual. Being of a higher social rank than the rest of his people, he can decide on the villager's life, as he can cast the villager out. He is never wrong. He need give no justification to anybody, and his decision is final and irreversible. It is without any appeal. In this socio-cultural context, it is not appropriate for the chief to apologize.

Leech (1983) notes that the realization of an apology provides benefit for the hearer and is to some degree at cost to the speaker. The act of apologizing being face-saving for the hearer and face-threatening for the speaker (Brown and Levinson 1978), the offender of the higher social rank avoids apologizing to an offended individual of a lower social rank to save face. For instance, the relationship between the chief and the villager in the Luba tribe being defined by the socio-cultural norms as that of a dominant to a dominee, a relationship of great social distance and differential 
power, the dominant, i.e., the chief or the boss in the case of our study, avoids damaging his or her face by not apologizing to the dominee, i.e., the villager or the subordinate who, in this case, prefers to exhibit a negative face.

Another type of relationship which could be considered to be of unequal status, though familiar, is that existing between parents and children. When considered in the light of the socio-cultural contexts of the Luba people, the relationship between the boss and the subordinate parallels that of the chief of a village and his villagers, that of an old person and a young person, and somewhat that of a parent and his or her child, i.e., of social distance and differential power. That the relationship between parents and their children, in Africa, can be compared to that of a chief to his people is shown in Naden's (1986) discussion of the Mamprusi ethnic group where he draws a parallel between the father's authority and the chief's by noting,

If he (the paramount chief of all the Mamprusi) were to enter another chief's domain, there would be a tension between his intrinsic paramountcy and that of the village chief in his own village. This is the same principle as we have seen operating in father-son relationships. (Naden 1986: 170)

As reported by Radcliffe-Brown (1975), in Africa generally there is a marked condition of restraint on the behavior of children in the presence of their parents. "The normal relation between parents and children," he says, "can be described as one of superordination and subordination." Any relationship of subordination, if it is to work, requires that the person in the subordinate position should maintain an attitude of respect towards the other. Radcliffe-Brown (1975) goes on to say that there exists a relation of social inequality between proximate generations, and this is commonly generalized so that a person is subordinate and owes respect to his or her relatives of the first ascending generation - that of his or her parents. As for other members of the family, e.g., siblings, the interaction between them is determined by seniority. Notice that seniority is not always determined by age, as Naden (1986) points out:

Age is to be considered primarily in chronological terms, though within a kinship framework seniority belongs to a member of a line whose linking relative was the elder, and this may be described by members simply in terms of age. Thus, a young boy may be said to be senior brother to an elderly chief because the boy's grandfather was genealogically the elder brother of the chief's grandfather. In general, however, the older the person, the higher the status. (Naden 1986: 166)

Regarding the expression of apologies by the subjects to their parents, the results of this study show that 66 percent of monolingual speakers responded that they would not express an apology to either their mother or their father whereas 100 percent of trilingual speakers said they would. The difference is statistically significant (chi-square of 63.724, $\mathrm{p}=0.00<0.001, \mathrm{df}=1$ ) and suggests that the two groups behave differently with respect to the norms of Ciluba. As discussed above in this paper, in the case of parents and children, the socio-cultural norms of Ciluba require that the latter show respect and restraint toward the former. Children avoid offending their parents. Moreover, it is not customary, in this tribe, for individuals with a relationship of familiarity such as between parents and children, older brothers or sisters and younger brothers or sisters, or between friends to apologize to each other for trivial offenses. In other words, when the relationship between participants is of familiarity, as between 
friends, or parents and children, Luba socio-cultural contexts do not allow for them to apologize to each other unless the offense committed is serious. In fact, the same data show that, despite the small percentage of subjects who responded positively to the item, only 30 percent of monolingual speakers of Ciluba and 20 percent of the same group responded that they would apologize respectively to a friend or a co-worker, whereas 100 percent of trilingual speakers responded that they would apologize to both categories of individuals. As mentioned above, Luba socio-cultural contexts do not require them to do so because of the friendly and familiar relationship which exists between them. As quoted above in this paper, Brown and Levinson $(1978,1987)$ argue that the greater the social distance, the heavier the weighting of the Face Threatening Act (FTA). Thus, as Holmes (1989) points out, one might expect to find apologies to strangers occurring more often than to friends and intimates. Expressing an apology to a friend would constitute an "ironical and sarcastic" act, as pointed out by Davies (1987) when comparing Moroccan Arabic speakers with the British English speakers in their expression of gratitude. It's a marker of "distance" and "over-formality." This intergroup difference is statistically significant (chi-squares of $84, \mathrm{p}<0.001$, $\mathrm{df}=1$ for the category of co-worker and 69.176, $\mathrm{p}<0.001, \mathrm{df}=1$ for the category of friend) (see Figure 1 below).

Figure 1: chi-square tests comparing Ciluba monolingual and trilingual speakers' responses

To item 9A (co-worker and friend) (df 1)

Co-worker: 84, $\mathrm{p}=0.00<0.001$

Friend: 69.176, $\mathrm{p}=0.00<0.001$

The significance of the differences in both cases indicates that the trilingual subjects deviate from the socio-cultural norms of Ciluba which do not allow for them to apologize to a friend whereas the majority of monolingual subjects follow those norms. When, why, and to whom an apology must be expressed are questions which need to be considered before the performance of an act of apology in Ciluba. Davies (1987) reports a similar behavior in the expression of gratitude by Moroccan Arabic speakers as compared with the British English speakers. He remarks:

While both Moroccan Arabic speakers and British English speakers recognize the act of thanking, or acknowledge gifts, services, or concern as a polite way of responding to certain kinds of behaviour on the part of their addressee, they nevertheless differ in their views of where exactly an expression of thanks is needed. The British tend to utter 'thank you' in response to the smallest service - to one who has passed the salt across the table, closed the door, or picked up something the speaker dropped - and the formula may be used to a complete stranger or a close relative, to a superior or inferior. In Moroccan Arabic, however, such small gestures will typically not warrant thanks at all, and to use a formula such as /barakallahufik/ in response to such a trivial service might seem ironical or sarcastic instead of polite. Nor are such formulas much used between intimate acquaintances; Moroccans who used one to thank their mother for preparing a meal, or their brother for giving them a lift, might well find themselves accused of being distant or over-formal. Accordingly, English-speaking learners of Arabic who distribute thanks as they would in English may be perceived as insincere 
or stilted, while a Moroccan who applies the Arabic conventions for thanking when speaking English will often appear impolite or unappreciative. (Davies 1987: 85)

Notice that a child or a friend may commit a serious offense against her or his parent or another friend. In this case, the offender is usually required to apologize. Sometimes, if the offense has deteriorated the relationship between the members of the tribe, the offender is required to apologize in public, i.e., before the influential member of the tribe. One way of interpreting the socio-cultural behavior of the subjects in their responses to this item is that the monolingual speakers who said that they would not express an apology to their parents might have conformed to the socio-cultural norms of Ciluba which do not allow them to offend their parents in the first place; hence there is no need to apologize. Those who responded that they would apologize to their parents might have been influenced by the urban environment ${ }^{8}$ with its cultural mixture. The trilingual subjects might have been influenced by the norms of French and English in deviating from those of their native Ciluba and/or the urban environment.

In general, it would be demeaning and deviating from the norms, among the Baluba, for an individual of a higher social rank to apologize to an individual of a lower social rank, for an old person to apologize to a young person, or for parents to apologize to their children, because of the type of relationship which exists between them, i.e., superordination vs. subordination. There exist cases where the social contexts do not require a young person to apologize to a high-ranking or old person, for instance, the case of a joking relationship, e.g., between grandparents and grandchildren. Radcliffe-Brown (1975) notes that the "joking" relationship in its reciprocal form can be regarded as a kind of friendliness expressed by a show of hostility. The mutual abusive behavior would be simple hostility in other connections, but the joking relatives are required not to take offense and to respond in the same way. The relation between grandparents and grandchildren is institutionalized in various ways in African and other societies. There is a widespread custom of privileged familiarity between grandchildren and grandparents. Grandchildren may tease their relatives and joke at their expense. It is a relation of friendly familiarity and almost of social equality. This relationship between grandparents and grandchildren is so familiar and devoid of any social distance that, as Radcliffe-Brown (1975) observes, the principle makes itself apparent in some African peoples (this is true also for the Baluba) in a peculiar feature of the kinship terminology, whereby the term that primarily means "wife" is applied by men to their granddaughters or grandmothers, and women apply to their grandsons the term meaning "husband." For individuals of "joking” relationship such as grandparents and grandchildren, a so-called offense may be regarded as a kind of friendliness expressed by a show of hostility. The joking relatives are required not to take offense but to respond in the same way. Hence there is no need for them to apologize. Moreover, from the description of the relationship between grandparents and grandchildren, it becomes apparent that what could be considered to be an offense by somebody else is considered to be a case of genuine teasing or joking by grandparents and grandchildren.

It should be recalled that apologies in general, as Holmes (1986) argues, are expressed more to strangers than to friends and intimates. In confirmation of this observation, the data in Tables 1 and 2 show that 90 percent of the subjects in the group

8 The data for both Ciluba monolingual speakers and trilingual speakers were collected in Kinshasa, the capital city of the Democratic Republic of the Congo. 
of the monolingual speakers of Ciluba and 100 percent of the subjects in the group of the trilingual speakers responded that they would apologize to a store clerk and 100 percent in both groups responded that they would apologize to their neighbor.

According to Hymes (1977) social distance has been identified in the field of sociolinguistics as playing an important and influential role across a range of communities. The relationship between the store clerk and the customer differs widely in terms of how well they know each other, i.e. the degree of social distance which may exist between them. The data in Tables 1 and 2 suggest that, in the socio-cultural contexts of the Luba tribe, if the relationship between the participants is that of unfamiliarity, i.e., great social distance, the offender is required to apologize. In this case it is assumed that the offender is of inferior social status, i.e., of less power. If the offender is a superior, i.e., of greater power, the same socio-cultural contexts do not necessarily require apology to the offended inferior. The age and/or the social rank of the subjects will usually determine who is to apologize. For instance, if the customer who is an offender is of a higher social rank or if he or she is older than the offended store clerk, he or she might not apologize; but if the offender is a customer of lower social rank or younger than the offended store clerk, the Luba socio-cultural contexts require her or him to apologize as a mark of respect to an old person.

Interestingly enough, as in the case of the apologies expressed to the boss, 100 percent of the subjects in both groups responded that they would apologize to their neighbor. It is important to point out that in the African traditional village the neighbor is usually a member of the family, tribe, or clan. Hence it would not be necessary, within the frame of the socio-cultural contexts of this tribe, to apologize to a neighbor for a trivial offense, as in the case of parents and children, friend and friend, etc. as mentioned above, because there exists a relationship of familiarity. One way of explaining the monolingual subjects' behavior in their responses to this item is that, although there may exist some familiarity between the neighbors, there still exists some sort of social distance between them. As in the case of parents and children, social distance prevails over familiarity in deciding whether the subject may or may not apologize to a neighbor. A neighbor in an urban environment is not necessarily a member of the family, tribe, or clan.

In order to understand why these subjects responded that they might apologize to their neighbor, one has to consider social distance to be on a continuum, as in Figure 2, i.e., starting with less (-) social distance on the left end of the continuum and increasing in degrees along the continuum to reach more $(+)$ social distance on the right end.

Figure 2: Social Distance Continuum

distance $(-)<-------------------------->(+)$ distance

(friend, co-worker, neighbor, subordinate, ... boss)

The more one moves toward the right, the greater the need to use expressions of politeness. Conversely, the more one moves to the left, the less the need for the use of politeness expressions. Table 3 below provides a summary of some possible occurrences of apology triggered by an offense based on the relationship and status of participants.

Before closing the discussion of this item, it is worth pointing out that the raw data in Tables 1 and 2 also reveal that the trilingual speakers show some inconsistency 
in their responses to this item when compared to the monolingual speakers of Ciluba. On the one hand, they seem to behave within the paradigms of the socio-cultural contexts of Ciluba in responding that they would apologize to a boss (100\%), a store clerk (100\%), and a neighbor (100\%), and that they would not apologize to a subordinate (80\%). On the other hand, they deviate from the same socio-cultural contexts and behave according the paradigms of the French and English socio-cultural contxts by responding that they would apologize to their co-worker $(100 \%)$, their friend $(1000 \%)$, and their mother and father (100\%). This inconsistency can be hypothesized to be a result of the interference between their native Ciluba and the two target languages, English and French, and/or the influence of the urban environment.

Table 3: Apology Realization Triggered by an Offense as Defined by the Luba Socio-cultural Contexts

\begin{tabular}{|c|c|c|c|c|}
\hline Relationship & Status & Offender & Offended & Apology \\
\hline Familiar & Equal & $\begin{array}{l}\text { Friend, } \\
\text { grandparents }\end{array}$ & $\begin{array}{l}\text { Friend, } \\
\text { grandchildren }\end{array}$ & No \\
\hline Familiar & $\begin{array}{l}\text { Unequal } \\
>9\end{array}$ & $\begin{array}{l}\begin{array}{l}\text { Old person } \\
\text { (sibling) }\end{array} \\
\text { parent } \\
\text { Young person } \\
\text { (sibling) } \\
\text { child }\end{array}$ & $\begin{array}{l}\begin{array}{l}\text { Young person } \\
\text { (sibling) }\end{array} \\
\text { child } \\
\text { Old person } \\
\text { (sibling) } \\
\text { parent }\end{array}$ & $\begin{array}{l}\text { No } \\
\text { No } \\
\text { No } \\
\text { No }\end{array}$ \\
\hline Unfamiliar & Equal & $\begin{array}{l}\text { Neighbor, } \\
\text { customer }\end{array}$ & $\begin{array}{l}\text { Neighbor, store } \\
\text { clerk }\end{array}$ & Yes \\
\hline Unfamiliar & $\begin{array}{l}\text { Unequal } \\
> \\
<\end{array}$ & $\begin{array}{l}\text { Chief, boss, } \\
\text { customer, old } \\
\text { person }\end{array}$ & $\begin{array}{l}\text { Villager, } \\
\text { subordinate, } \\
\text { store clerk, } \\
\text { young person } \\
\text { Chief, boss, } \\
\text { store clerk, } \\
\text { young person }\end{array}$ & Yes \\
\hline
\end{tabular}

It should also be observed that, for some categories of individuals, the raw data from the female subjects in the monolingual group indicate that they are more conservative regarding the socio-cultural contexts of Ciluba in their responses to the item than the male subjects in this group. For instance, for the category of subordinate, 16 percent more male than female subjects responded that they would apologize to a subordinate; for the category of friend, 12 percent more male subjects responded that they would apologize to a friend; and for the categories of mother and father, 12 percent offended

${ }^{9}>$ means the offender is superior to the offended, < means the offender is inferior to the 
more male subjects responded that they would apologize to their mother or their father. In order to see whether the difference in proportions between the male and female subjects in the group of Ciluba monolingual speakers in their responses to expressing apologies to those individuals is statistically significant, chi-square tests were performed. The results from Figure 3 below show that there is no significant difference in their responses (chi-squares of $1.471, \mathrm{p}>0.001$, df $=1$ for the category of subordinate; $0.857, \mathrm{p}>0.001, \mathrm{df}=1$ for the category of friend; and $0.802, \mathrm{p}>6: 001, \mathrm{df}$ $=1$ for the category of mother and father).

Figure 3: chi-square tests comparing sex variation in monolingual subjects' responses to item 9A (df 1)

Subordinate: $1.471, \mathrm{p}=0.225>0.001$.

Friend: $0.857, \mathrm{p}=0.354>0.001$.

Mother and Father: 0.802, $\mathrm{p}=0.370>0.001$.

In other words, both male and female subjects in this group behave similarly in their responses. Likewise, subjects of both sexes in the trilingual group tended to behave within the paradigms of the socio-cultural contexts of French and English, and in so doing deviate from the paradigms as defined by the socio-cultural contexts of their native Ciluba.

\subsubsection{Subjects' responses to item 9B}

The responses to item 9B, where the subjects were asked to say whether they would or would not complain to individuals listed in the item as shown in Tables 4 and 5, reveal again that the trilingual speakers deviate from the socio-cultural norms of their native Ciluba in their responses and behave more like French and English monolingual speakers than do the majority of monolingual speakers of Ciluba. As the raw data in these tables show, zero percent of the monolingual speakers vs. 83 percent of the trilingual speakers responded that they would complain to their boss.

The fact that the difference in the two proportions is statistically significant (chi-square of 53.185, $\mathrm{p}=0.00<0.001$, $\mathrm{df}=1$ ) shows that the trilingual speakers deviate from the norms of Ciluba and behave in a similar way as both French and English monolingual speakers who reported that they would complain to their boss whereas the group of Ciluba monolingual speakers follow a different norm. It might also be possible that the group of Ciluba monolingual speakers would not complain to their boss because they are involved in low status jobs with a big distance between them

Table 4: Percentages of Ciluba monolingual subjects`responses to item 9B

\begin{tabular}{|l|l|l|l|l|}
\hline $\begin{array}{l}\text { Categories } \\
\text { of } \\
\text { individuals }\end{array}$ & Responses & $\begin{array}{l}\text { Female } \\
\text { Subjects } \\
\mathrm{n}=25\end{array}$ & $\begin{array}{l}\text { Male } \\
\text { Subjects } \\
\mathrm{n}=25\end{array}$ & $\begin{array}{c}\text { Total } \\
\mathrm{n}=50\end{array}$ \\
\hline Boss & $\begin{array}{l}\text { Yes } \\
\text { No }\end{array}$ & $\begin{array}{l}(0 \%) \\
25(100 \%)\end{array}$ & $\begin{array}{l}0(0 \%) \\
25(100 \%)\end{array}$ & $\begin{array}{l}0(0 \%) \\
50(100 \%)\end{array}$ \\
\hline subordinate & Yes & $25(100 \%)$ & $25(100 \%)$ & $50(100 \%)$ \\
\hline
\end{tabular}




\begin{tabular}{|l|l|l|l|l|}
\hline & No & $0(0 \%)$ & $0(0 \%)$ & $0(0 \%)$ \\
\hline co-worker & Yes & $25(100 \%)$ & $25(100 \%)$ & $50(100 \%)$ \\
& No & $0(0 \%)$ & $0(0 \%)$ & $0(0 \%)$ \\
\hline store clerk & Yes & $25(100 \%)$ & $25(100 \%)$ & $50(100 \%)$ \\
& No & $0(0 \%)$ & $0(0 \%)$ & $0(0 \%)$ \\
\hline Neighbor & Yes & $25(100 \%)$ & $25(100 \%)$ & $50(100 \%)$ \\
& No & $0(0 \%)$ & $0(0 \%)$ & $0(0 \%)$ \\
\hline Friend & Yes & $25(100 \%)$ & $25(100 \%)$ & $50(100 \%)$ \\
& No & $0(0 \%)$ & $0(0 \%)$ & $0(0 \%)$ \\
\hline Mother & Yes & $9(36 \%)$ & $12(48 \%)$ & $21(42 \%)$ \\
& No & $16(64 \%)$ & $13(52 \%)$ & $29(58 \%)$ \\
\hline Father & Yes & $9(36 \%)$ & $12(48 \%)$ & $21(42 \%)$ \\
& No & $16(64 \%)$ & $13(52 \%)$ & $29(58 \%)$ \\
\hline
\end{tabular}

Table 5: Trilingual subjects' responses to item 9B

\begin{tabular}{|c|c|c|c|c|}
\hline $\begin{array}{l}\text { Categories } \\
\text { of } \\
\text { individuals }\end{array}$ & Responses & $\begin{array}{l}\text { Female } \\
\text { subjects } \\
\quad \mathrm{n}=35\end{array}$ & $\begin{array}{l}\text { Male } \\
\text { subjects } \\
n=35\end{array}$ & $\begin{array}{l}\text { Total } \\
\mathrm{n}=70\end{array}$ \\
\hline Boss & $\begin{array}{l}\text { Yes } \\
\text { No }\end{array}$ & $\begin{array}{ll}28 & (80 \%) \\
7 & (20 \%) \\
\end{array}$ & $\begin{array}{l}30(86 \%) \\
5 \quad(14 \%) \\
\end{array}$ & $\begin{array}{l}58(83 \%) \\
12(17 \%) \\
\end{array}$ \\
\hline subordinate & $\begin{array}{l}\text { Yes } \\
\text { No }\end{array}$ & $\begin{array}{l}35(100 \%) \\
0 \quad(0 \%)\end{array}$ & $\begin{array}{l}35(100 \%) \\
0 \quad(0 \%)\end{array}$ & $\begin{array}{ll}70 & (100 \%) \\
0 & (0 \%)\end{array}$ \\
\hline co-worker & $\begin{array}{l}\text { Yes } \\
\text { No }\end{array}$ & $\begin{array}{l}35(100 \%) \\
0 \quad(0 \%)\end{array}$ & $\begin{array}{l}35(100 \%) \\
0 \quad(0 \%)\end{array}$ & $\begin{array}{ll}70 & (100 \%) \\
0 & (0 \%)\end{array}$ \\
\hline store clerk & $\begin{array}{l}\text { Yes } \\
\text { No }\end{array}$ & $\begin{array}{l}35(100 \%) \\
0 \quad(0 \%)\end{array}$ & $\begin{array}{l}35(100 \%) \\
0 \quad(0 \%)\end{array}$ & $\begin{array}{l}70(100 \%) \\
0 \quad(0 \%)\end{array}$ \\
\hline Neighbor & $\begin{array}{l}\text { Yes } \\
\text { No }\end{array}$ & $\begin{array}{l}35(100 \%) \\
0 \quad(0 \%)\end{array}$ & $\begin{array}{l}35(100 \%) \\
0 \quad(0 \%)\end{array}$ & $\begin{array}{l}70(100 \%) \\
0 \quad(0 \%)\end{array}$ \\
\hline Friend & $\begin{array}{l}\text { Yes } \\
\text { No }\end{array}$ & $\begin{array}{l}35(100 \%) \\
0 \quad(0 \%)\end{array}$ & $\begin{array}{l}35(100 \%) \\
0 \quad(0 \%)\end{array}$ & $\begin{array}{l}70(100 \%) \\
0 \quad(0 \%)\end{array}$ \\
\hline Mother & $\begin{array}{l}\text { Yes } \\
\text { No }\end{array}$ & $\begin{array}{l}23(66 \%) \\
12(34 \%) \\
\end{array}$ & $\begin{array}{l}18 \text { (51\%) } \\
17(49 \%) \\
\end{array}$ & $\begin{array}{l}41(59 \%) \\
29(41 \%) \\
\end{array}$ \\
\hline Father & $\begin{array}{l}\text { Yes } \\
\text { No }\end{array}$ & $\begin{array}{l}23(66 \%) \\
12(34 \%) \\
\end{array}$ & $\begin{array}{l}18 \text { (51\%) } \\
17(49 \%)\end{array}$ & $\begin{array}{l}41(59 \%) \\
29(41 \%) \\
\end{array}$ \\
\hline
\end{tabular}

and their bosses whereas the social distance between the trilingual speakers and their bosses is less due to their higher status jobs. Another fact to point out from these data is that 42 percent of the monolingual speakers vs. 59 percent of the trilingual speakers responded that they would complain to their mother and their father. This difference in proportions in the responses of the two language groups is not statistically significant (chi-square of 3.207, $\mathrm{p}=0.073>0.001, \mathrm{df}=1$ ), however. Both groups of subjects show a similar tendency, i.e., to complain to their parents. This tendency is a deviation from the socio-cultural norms of Ciluba because, as mentioned above, the attitude of respect and submission which is required on the part of children does not allow for them to complain to their parents directly but through their grandparents or a person of their 
parents' generation. This deviation can perhaps be explained in the monolingual speakers by the influence of the urban environment and in the trilingual speakers by the norms of French and English as well as the urban environment.

It is worth pointing out that contrary to the case of apology where either the relationship or the status of the participants may determine whether or not a realization of an apology is possible, in the complaint case only the status of the interactants determines whether or not the complaint may occur. In Luba culture, the relationship between the chief and the villager, as stated earlier, parallels in a certain way that of parents and children. Despite the familiarity which exists between parents and children, this relationship is still of great differential power. Naden 1986) notes:

The relative status of a particular dyad of members of the society is also influenced by their kinship links. A senior kinsman is given extra respect irrespective of ego's own status. Particular deference is shown to one's own father and mother and one's wife's parents. (Naden 1986: 168)

The chief, as well as the parents, is never wrong. There is, therefore, no reason for the villager or the child to complain to the chief or the parents. However, as pointed out above, in the case of parents and children, the latter can complain about the parents to a third person, an older member of the community or family, usually a grandparent who is the person allowed to interfere in their relationship. As Radcliffe-Brown (1975) noted the relation between two proximate generations is normally one of essential inequality, authority, and protective care on the one side, respect and dependence on the other. Notice that grandparents and grandchildren can complain to each other directly because the relationship between these two generations is that of both non-distance and non-power. Luba socio-cultural contxts allow for the grandparents and grandchildren to address each others with jokes and/or teasing. As D'Amico-Reisner (1983) argues, the amount and kind of information speakers share determine what they find to be offensive. When and where a complaint can be verbalized depends upon the way in which a particular speaker-hearer relationship is defined. What may be offensive for one individual may not be offensive for another. Kuper (1975) notes that in some African societies it is culturally shared knowledge that it is an offense for a wife to utter some words to or about her husband or husband's family members.

A similar custom exists in the Luba culture where a low-ranking individual is not allowed to call a chief, a boss, or an old person by name only. These individuals are always addressed or referred to by title alone or by title followed by name, e.g., Chief $\mathrm{X}$, senior brother or sister $\mathrm{Y}$, etc.; however, a chief, a boss, or an old person is allowed to call a villager, a subordinate, or a young person by name alone. In some other cultures, e.g., in American culture, it is common for a boss and an employee to call each other by their first names. As Naden (1986) says,

Some societies have an egalitarian mold ... it is an oversimplification but not a total distortion to say that in America you can greet anyone with 'Hi!' (whether, however, one could say, 'Hi, Mr. President, Sir!', 'Hi, Ron!', or 'Hi, ugly!' would need more careful attention. (Naden 186: 168)

Culturally shared knowledge plays an important role in social interaction. Drawing a parallelism between Goffman's (1971) discussion of offense and the speech act of complaint, one is inclined to say that expressions of complaint cannot occur in 
contexts where some social or personal expectation has not been violated or is not in danger of being violated at some point in future or conditional time. In other words, wherever there is an offense, there is a complaint; however, as I argued above, in the case of grandparents and grandchildren or friends in African societies, not every offense triggers an expression of complaint. It depends on who is the offender rather than on what social or personal expectation has been violated or is in danger of being violated at some point in future or conditional time. All depends on the identity of the participants as Lafage (1986) explains, "In traditional society, the identity of the participants seems extremely important, whatever the topic of the communication may be, and whether it is formal (constrained) or informal.”

To come back to whether one has to greet someone using her or his title, African socio-cultural contexts, in general, and Luba socio-cultural contexts, in particular, require the greeter to use either the title alone, or the title followed by the name. The title followed by the name is usually used when a distinction between two or more individuals is necessary. It would be an offense for an individual to greet a socially high-ranking individual by just saying "hi," which constitutes an offense to the socially high-ranking person's face, e.g., senior brother or sister, parents' generation, but not grandparents' generation, because when used for grandparents, it would sound ironical or joking.

If a complaint can be considered to be a challenge to someone, then, as Labov and Fanshel (1977) argue, a possible reaction to it can be "defence" or "admission." The relationship between the chief and the villager and that between the parents and their child being defined in African societies as that of superior to inferior, the villager or the child avoids threatening the chief's or parents `ace, i.e., avoids putting the chief or the parents in a position where they would likely opt for a "defence" with all the possible consequences that may result from it. Moreover, in those societies, it is considered to be a mark of politeness, respect, and submission for individuals of a lower social rank not to complain to individuals of a higher social rank, avoiding, in this way. damage to their face; hence there is avoidance of complaint to the chief or the boss by a villager or a subordinate and to the parents by the children. That in Africa silence would be the norm to follow in this case is shown by the following observation by Lafage (1986):

It is true that silence in an African society does not have the negative function that it exercises in European social relations. During a meeting, no one has to ramble on just because it would be impolite to be silent. Quite the opposite, silence is something positive. A child or an adolescent is severely reprimanded if he opens his mouth when no one has given him permission to speak by addressing him with a question. Silence appears as a mark of politeness and respect for others. The spoken word is sacred, and an adult who uses it thoughtlessly loses face. (Lafage 1986: 157)

One way of using words "thoughtlessly," in the African society, would be for a villager to complain to the chief or for a child to complain to his or her parents. With regard to the female and male Ciluba monolingual speakers' responses to this item, the raw data indicate again that female subjects seem to be more conservative in responding to the item than male subjects. For instance, eight percent more male subjects responded that they would complain to their mother or father than the female subjects. This difference shows no statistical significance (chi-square of 0.739, $\mathrm{p}=0.390>0.001$, $\mathrm{df}=$ 1). Both male and female subjects behave similarly as far as this response is concerned. They either follow or deviate from the paradigms of the socio-cultural contexts of 
Ciluba to the same degree. Table 6 below represents possible realization of complaint as defined within the Luba socio-cultural contexts.

Table 6: complaint realization as defined within the Luba socio-cultural contexts

\begin{tabular}{|c|c|c|c|c|}
\hline Relationship & Status & Complaint & Complainee & Complaint \\
\hline Familiar & Equal & Friend & Friend & yes \\
\hline Familiar & $\begin{array}{l}\text { Unequal } \\
> \\
<\end{array}$ & $\begin{array}{lr}\begin{array}{l}\text { Parent, old } \\
\text { person or } \\
\text { older sibling }\end{array} \\
\begin{array}{lr}\text { Child, young } \\
\text { person or } \\
\text { younger } \\
\text { sibling }\end{array}\end{array}$ & $\begin{array}{l}\text { Child, young } \\
\text { person } \\
\text { or younger } \\
\text { sibling } \\
\text { Parent, old } \\
\text { person or older } \\
\text { sibling }\end{array}$ & Yes \\
\hline Unfamiliar & Equal & $\begin{array}{l}\text { Neighbor, } \\
\text { customer }\end{array}$ & $\begin{array}{l}\text { Neighbor, } \\
\text { store clerk }\end{array}$ & Yes \\
\hline Unfamiliar & $\begin{array}{l}\text { Unequal } \\
>\end{array}$ & $\begin{array}{l}\text { Customer, } \\
\text { chief, boss, } \\
\text { old person } \\
\text { Customer, } \\
\text { villager, } \\
\text { subordinate, } \\
\text { young person }\end{array}$ & $\begin{array}{l}\text { Store clerk, } \\
\text { villager, } \\
\text { subordinate, } \\
\text { young person } \\
\\
\text { Store clerk, } \\
\text { chief, boss, old } \\
\text { person }\end{array}$ & No \\
\hline
\end{tabular}

\section{Conclusion}

Despite the fact that some variables such as social class and social settings were difficult to control, it is worth noting that the findings are suggestive of the way these different groups would decide whether or not to perform the two speech acts.

Apart from establishing sociolinguistic baselines for each of the three languages under study, the main concern of this study was to see whether the trilingual speakers deviate or not from the paradigms of the socio-cultural contexts of their native Ciluba in their responses to the items presented in the questionnaire. The analysis of the questionnaire has shown that all the subjects make a clear distinction of the two speech acts under study and that they are aware of different conditions which are necessary to obtain in order for each one of these speech acts to occur.

With respect to the realization of the two speech acts under investigation, it was found that Ciluba socio-cultural contexts that allow the occurrence of the speech acts of apologizing and complaining are different from French and English socio-cultural contexts, which are similar to each other. For instance, whereas the French and English monolingual speakers do not see any inconvenience to express an apology or a complaint to all the individuals suggested in items 9A and 9B, the majority of Ciluba monolingual speakers and some of the trilingual speakers, who conform to the 
paradigms of the socio-cultural norms of Ciluba, show a different behavior. In other words, whereas the socio-cultural contexts of Ciluba consider social distance and power in deciding on the realization of these two speech acts, French and English socio-cultural contexts do not. Regarding the speech act of apology, the socio-cultural contexts of Ciluba do not allow the subjects to apologize to familiar, intimate or low status individuals such as friends or subordinates but to unfamiliar and high status ones. With regard to the speech acts of complaining, the same socio-cultural contexts allow the subjects to complain to both familiar and unfamiliar low status individuals.

Interestingly enough, the analysis of the results has indicated that, in most cases, the trilingual speakers show some deviation from the paradigms of the socio-cultural contexts of Ciluba (which might be the result of the influence of the two target languages) in their responses to the two items in the questionnaire and therefore behave socio-culturally more like the monolingual speakers of the two target languages which they use on a daily basis. For instance, the majority of the subjects responded that they would apologize to their friends (100\%) and that they would complain to their boss (80\%), following the paradigms of the socio-cultural contxts of French and English. As for the monolingual speakers of Ciluba, despite the fact that they indicate some urban influence as a result of culture mixture in their responses to the items, they conform, generally speaking, to the socio-cultural contexts of their native Ciluba. Differences between the two language groups in terms of deviation from the socio-cultural contexts of Ciluba in their responses to some items have proven to be statistically significant.

Finally, it should be noted that the results show some significant cross-cultural differences which are worth consideration in the interaction of the individuals from French, English, and Luba cultures. An employee may suffer from a boss's misunderstanding of her or his behavior or vice versa if she or he is not aware of the socio-cultural beliefs of the employee or vice versa that define when and to whom to express the two speech acts. For instance, an English or French speaking boss might keep on offending an African employee whose socio-cultural beliefs do not allow to complain to a superior, thinking that she or he behaves properly and that the employee would complain if she or he offended her or him; or an English or French speaking employee might feel frustrated that her or his African boss does not care, she or he does not apologize any time she or he offends her or him. Misunderstandings and misjudgments can occur when there is an interaction between people from the two target-language culture and people from the Luba culture.

\section{References}

Blum-Kulka, S. (1982) Learning how to say what you mean in a second language. A study of the speech act performance of learners of Hebrew as a second language. Applied Linguistics 3: 29-59.

Blum-Kulka, S., J. House, and G. Kasper (eds.) (1989) Investigating cross-cultural pragmatics: An introductory overview. Cross-cultural pragmatics: Requests and apologies. Vol. XXXI. Norwood, New Jersey: Ablex, pp. 1-34.

Brown, P., and S. Levinson (1978) Universals in language usage: Politeness phenomena. In E.N. Goody (ed.), Questions and politeness: Strategies in social interaction. Cambridge: Cambridge University Press.

Brown, P., and S. Levinson (1987) Politeness: Some universals in language usage. Cambridge: Cambridge University Press. 
Carrell, P.L., and B.H. Konneker (1981) Politeness: Comparing native and non-native judgments. Language learning 31.1: 17-30.

Castello, K. (1981) Contrastive analysis; speech acts: Apologies. Los Angeles: ESL Section, Department of English, UCLA.

Chen, Rong (1993) Responding to compliments: A contrastive study of politeness strategies between American English and Chinese speakers. Journal of Pragmatics 20: 49-75.

Chen, Rong (2001) Self-politeness: A proposal. Journal of Pragmatics 33: 87-106.

Daikuhara, Midori (1986) A study of compliments from a cross-cultural perspective: Japanese vs. American English. The PENN working papers in educational linguistics. Fall 1986: 103-134.

D’Amico-Reisner, L. (1983) An analysis of the surface structure of disapproval exchanges. In N.Wolfson and E. Judd (eds.), Sociolinguistics and Language Acquisition. Rowley, Mass.: Newbury House.

Davies, E.E. (1987) A contrastive approach to the analysis of politeness formulas. Applied Linguistics 8.1: $75-88$.

Eisenstein, M., and J.W. Bodman (1986) 'I very appreciate': Expressions of gratitude by native and nonnative speakers of American English. Applied linguistics 7.2: 167-185.

Fishman, Joshua (1965) Who speaks what language to whom and when? La linguistique 2: 67-88.

Goffman, E. (1971) Relations in public: Microstudies of public order. Harmondsworth, England: Penguin.

Holmes, Janet (1989) Sex differences and apologies: One aspect of communicative competence. Applied Linguistics 10.2: 194-213.

Hymes, D. (1977) Foundations in sociolinguistics. London: Longman.

Kuper, Hilda (1975) Kinship among the Swazi. In A.R. Radcliffe-Brown and D. Forde (eds.), African systems of kinship and marriage. Oxford: Oxford University Press, pp. 86-110.

Labov, W. (1972) Sociolinguistic patterns. Oxford, England: Basil Blackwell.

Labov, W., and D. Fanshel (1977) Therapeutic discourse: Psychotherapy as a convention. New York: Academic Press.

Lafage, Suzanne (1986) Outline of practical frame of reference for sociolinguistic analysis in an African context. In G. Huttar and K. Gregerson (eds.), Pragmatics in non-Western perspective. Summer Institute of Linguistics Publications in Linguistics. Texas: The Summer Institute of Linguistics and the University of Texas at Arlington 73: 143-159.

Lee, Cynthia (2004) Written requests in e-mails sent by adult Chinese users of English. Language culture and curriculum 17.1:58-72.

Lee, Cynthia (2005) A cross-linguistic study on the linguistic expressions of Cantonese and English requests. Pragmatics 15.4: 395-422.

Leech, G.N. (1983) Principles of pragmatics. London: Longman.

Naden, Anthony J. (1986) Social context and Mampruli greetings. In G. Huttar and K. Gregerson (eds.), Pragmatics in non-Western perspective. Summer Institute in linguistics publications in Linguistics. Texas: The Summer Institute of Linguistics and the University of Texas at Arlington 73: 161-199. 
Penalosa, Fernando (1981) Introduction to the sociology of language. Rowley, Mass. : Newbury House.

Radcliffe-Brow, A.R., and D. Forde (eds.) (1957) African Systems of Kinship and Marriage. Oxford: Oxford University Press.

Rubin, J. (1983) How to tell when someone is saying "no" revisited. In N. Wolfson and E. Judd (eds.), Sociolinguistics and language acquisition. Rowley, Mass.: Newbury House.

Sifianou, Maria (2001) “Oh, how appropriate” compliments and politeness. In A. Bayraktaroglu and M. Sifianou (eds.), Linguistic politeness across boundaries: The case of Greek and Turkish. Amsterdam/New York: John Benjamins Publishing Company, pp. 391-430.

Wieland, Molly (1989) Polite turn-taking in French/American cross-cultural conversation. Paper delivered at the $31^{\text {st }}$ annual meeting of the Midwest Modern Language Association. November 2-3, 1989 at the University of Minnesota/Twin Cities.

\section{Appendix: English version of the questionnaire}

Thank you very much for your help with this research project

1. Sex: $M \quad F$ (Please circle one)

2. Age: (15-20) (21-25) (26-30) (40 and +) (Please circle one)

3. Education: ........................... (Please give the highest level completed)

4. Major:

(If any)

5. What's your native language?

6. What languages do you speak? How well do you speak them? Circle one level for each language.

( (poor fair good very good excellent)

(poor fair good very good excellent)

(poor fair good very good excellent)

7. Can you discuss different topics easily with the native speakers in any of those languages? If so, which one(s)?

8. If you speak more than one language, please answer the following:

a. What language(s) do you frequently use at home for communication?

b. What language(s) do you frequently use outside home for communication and where?

9. In the following questions, imagine you are in different situations: e.g., a boss of a company, a salesperson, a cashier, a college student, etc.

A. Would you apologize to the following? If yes, in what language? (If you don't speak more than one language, just circle yes or no).
a. your boss
yes no language
b. a subordinate
yes no
c. a co-worker
yes no
language
d. a store clerk
yes no
language
e. a neighbor
yes no
language
f. a friend
yes no
language 
g. your mother

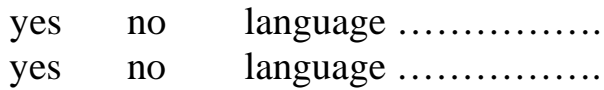

h. your father

B. Would you complain to the following about something they did? If yes, in what language? (If you don't speak more than one language, just circle yes or no).
a. your boss
b. a subordinate
c. a co-worker
d. a store clerk
e. a neighbor
f. a friend
g. your mother
h. your father

$\begin{array}{lll}\text { yes } & \text { no } & \text { language } \ldots \ldots \ldots \ldots \ldots \\ \text { yes } & \text { no } & \text { language } \ldots \ldots \ldots \ldots \ldots \\ \text { yes } & \text { no } & \text { language } \ldots \ldots \ldots \ldots \ldots \ldots \\ \text { yes } & \text { no } & \text { language } \ldots \ldots \ldots \ldots \ldots \ldots \\ \text { yes } & \text { no } & \text { language } \ldots \ldots \ldots \ldots \ldots \ldots \\ \text { yes } & \text { no } & \text { language } \ldots \ldots \ldots \ldots \ldots \ldots \\ \text { yes } & \text { no } & \text { language } \ldots \ldots \ldots \ldots \ldots \ldots \\ \text { yes } & \text { no } & \text { language } \ldots \ldots \ldots \ldots \ldots \ldots\end{array}$

